Beckett Matters 



\section{Beckett Matters}

Essays on Beckett's Late Modernism

S. E. Gontarski 
Edinburgh University Press is one of the leading university presses in the UK. We publish academic books and journals in our selected subject areas across the humanities and social sciences, combining cutting-edge scholarship with high editorial and production values to produce academic works of lasting importance. For more information visit our website: edinburghuniversitypress.com

(C) S. E. Gontarski, 20I7

Edinburgh University Press Ltd The Tun - Holyrood Road I 2(2f) Jackson's Entry

Edinburgh EH8 8PJ

Typeset in II/I 3 Adobe Sabon by Servis Filmsetting Ltd, Stockport, Cheshire, and printed and bound in Great Britain by CPI Group (UK) Ltd, Croydon CRo 4 YY

A CIP record for this book is available from the British Library

ISBN 978 I 4744 I 440 I (hardback)

ISBN 978 I 4744 I 44I 8 (webready PDF)

ISBN 978 I 4744 I 4425 (epub)

The right of S. E. Gontarski to be identified as the author of this work has been asserted in accordance with the Copyright, Designs and Patents Act 1988, and the Copyright and Related Rights Regulations 2003 (SI No. 2498). 